\title{
THE REUSED BLOCKS IN THE SOUTHERN CHAMBER OF AMENHOTEP II'S EDIFICE AT KARNAK TEMPLE
}

\author{
Abd-elsttar, Sh. \\ Egyptology dept., Faculty of Archaeology, Aswan Univ., Aswan, Egypt \\ E-mail address: shaimaaabdelsttar363@gmail.com
}

\begin{tabular}{|c|c|}
\hline Article info. & EJARS - Vol. 10 (1) - June 2020: 59-72 \\
\hline Article history: & Abstract: \\
\hline Received: 3/12/2019 & The present study explores the blocks that were reused in the \\
\hline Accepted: 13/5/2020 & southern chamber of Amenhotep II's edifice at the Karnak Temple. \\
\hline Doi: 10.21608/ejars.2020.98962 & $\begin{array}{l}\text { This edifice is located between the } I X^{\text {th }} \text { and the } X^{\text {th }} \text { pylons. The } \\
\text { blocks are sandstone and contain scenes and texts. The author } \\
\text { describes and translates them to investigate their association with } \\
\text { the rituals that occur in the edifice. Although the scenes of the }\end{array}$ \\
\hline $\begin{array}{l}\text { Keywords: } \\
\text { Amenhotep I/ }\end{array}$ & $\begin{array}{l}\text { blocks under investigation date back to Amenhotep II's second } \\
\text { jubilee, they were reused in other places. Some of them depict } \\
\text { scenes of the king with a deity, such as a block that showed King }\end{array}$ \\
\hline Edifice & Amenhotep II embraced by the god Amun. Moreover, they contained \\
\hline Reused block & various scenes, such as purification and offering. For example, the \\
\hline Chamber & offering scenes depict the offerings of three vessels, bread, goose, \\
\hline Karnak Temple & flowers, plants and fruits, and title of Amenhotep II. The author \\
\hline Annex & completing the study, the author will virtually reconstruct the edifice. \\
\hline
\end{tabular}

\section{Introduction}

The edifice of Amenhotep II is between the $\mathrm{IX}^{\text {th }}$ and the $\mathrm{X}^{\text {th }}$ pylons of Karnak Temple. It was dedicated to his $h b-s d$ $\therefore$ [1] festival. It was destroyed during the reign of Akhenaten but was restored in its original position by Seti I with the addition of several blocks of Akhenaten [2]. Van Siclen reported that the earlier structure of Amenhotep II was built for the king's second jubilee [3,4]. The edifice consists of a portico, a main hall, a northern chamber with an annex, and a southern chamber with three annexes $[5,6]$, which were used as storerooms. The southern chamber comprises a hall and three annexestwo at the east (Annex A and B) and one at the south (Annex C). The hall has four square pillars; the pillars S2 and S3 are partly preserved [7], but the two others (S1 and S4) [7] are now destroyed except for their bases. Moreover, the walls of the hall and the annexes have some reused inscribed blocks. The present paper is the second in a series for the complete publication of the southern chamber edifice of Amenhotep II at Karnak. It focuses on the reused blocks in the southern chamber by analyzing the reused blocks and trying to determine where they came from ${ }^{(a)}$.

\section{Reused Blocks}

\subsection{Reused blocks in the hall}

The hall of the southern chamber has reused blocks in three walls as follow: 


\subsubsection{The eastern wall is not decorated.}

2.1.2. The northern wall has two reused inscribed blocks on the east side of the entrance doorway, fig. (1-a).

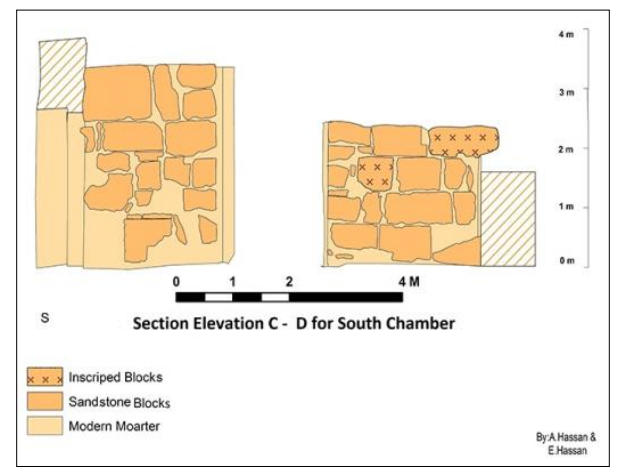

Figure (1-a) shows the reused inscribed blocks in the northern wall of the hall.

The first reused block is inscribed with a purification scene, which shows the remains of a human body. In front of him, there are ankh signs and an inscription reading, fig. (1-b). The second block in the same wall is decorated in sunk relief, with a partial image of Amun ithyphallic and the remnant of the divine beard, fig. (1-c)

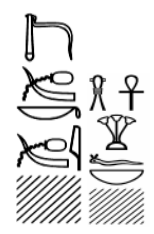

$\underline{d} d m d w^{C} b w . k{ }^{`} b w . i[\ldots .$.$] Recitation, your purification is my purification [......]$

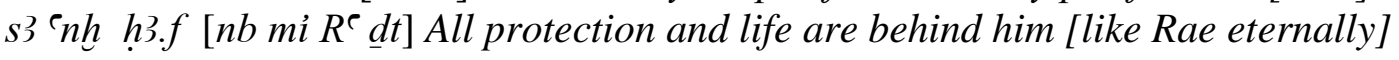

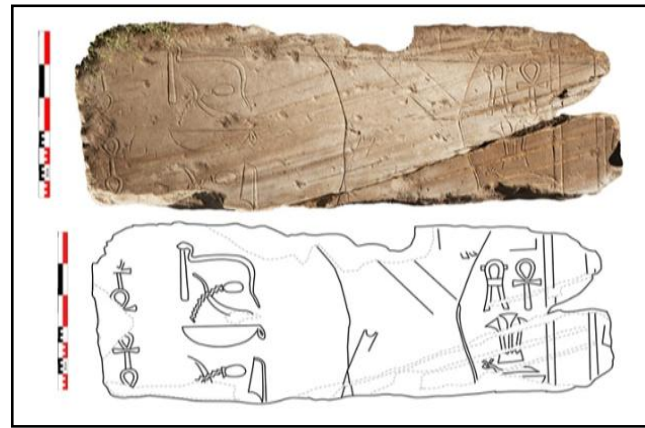

Figure (1-b) shows a purification scene on the northern wall.

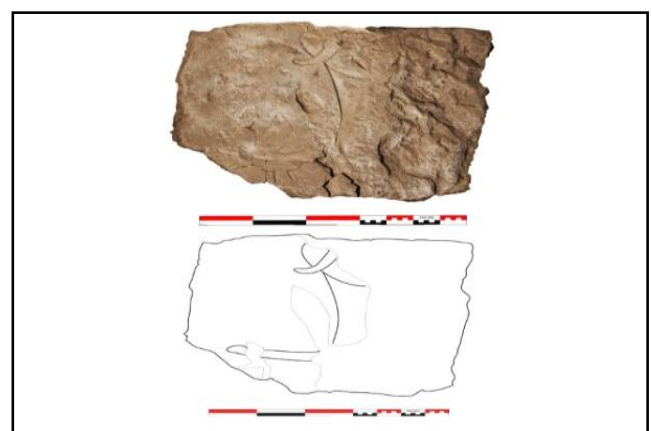

Figure (1-c) shows a partial image of Amun on the northern wall.

2.1.3.The western wall of the hall with the entrance to the two annexes A-B displays two reused inscribed blocks, fig. (2-a).

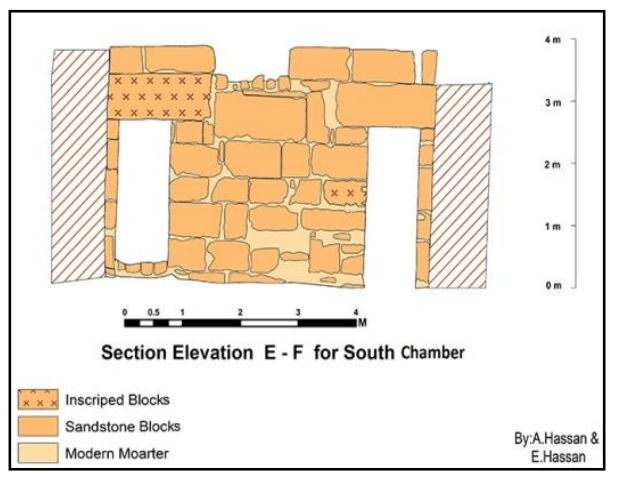

Figure (2-a) illustrates the reused inscribed blocks in the western wall of the hall. 
The first is the lintel at the top of the doorway to Annex B. Most of the inscri- ption is damaged and there are four horizontal lines, fig. (2-b)

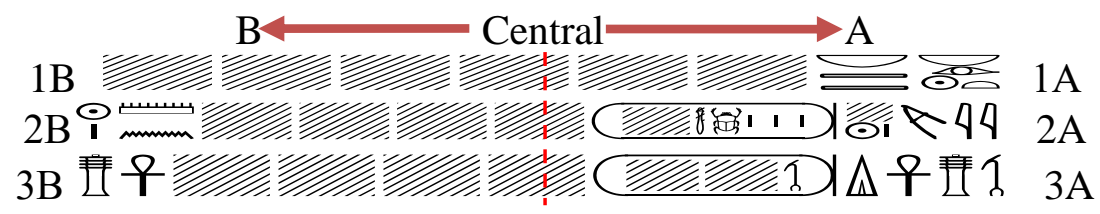

$1 \mathrm{~A}[n s w t-b i t j$ 3-hprw-Re $n t r-n f r] n b t 3 w j n b$ irt- $h t^{(\mathrm{b})}$

$1 \mathrm{~B}[$

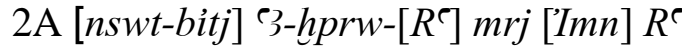

2B [nswt-bitj 3-hprw-R $m r j '] m n-R^{\ulcorner}$

3A [s3-Re'Imn-htp-ntr hk3] w3s(t)dj ${ }^{\top} n h d d w 3 s$

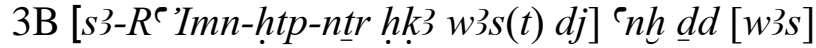

1A [the King of Upper and Lower Egypt Aa-kheperu-Ra, the good god], the lord of the two lands, lord of ritual practices

$1 \mathrm{~B}[$

2A [the king of upper and lower Egypt] Aa-kheperu-Ra, beloved of [Amun]-Ra

2B [the king of upper and lower Egypt Aa-kheperu-Ra, beloved of] Amun-Ra.

3A [The son of Ra Amun-Hotep the god, the ruler] of Thebes, who is given life, stability, and authority.

3B [The son of Rae Amun- Hotep the god, the ruler] of Thebes [Who is given] life, stability, and authority.

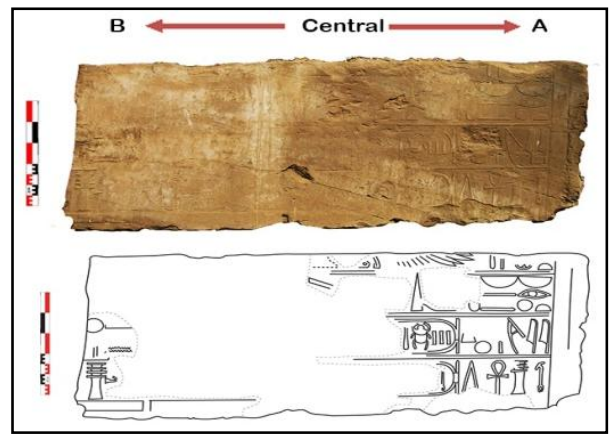

Figure (2-b) shows that the lintel has four horizontal lines.

The second block is decorated with a part of $h k r$ frieze ${ }^{\text {(c) }}$ one of the most famous friezes in ancient Egypt. Below is the tail of the vulture flying over the king's head to protect him followed by a partial inscription, fig. (2-c)

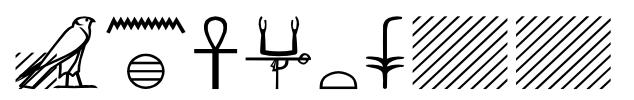

$k 3 n s w t$ [8] 'nh [1] Hr [.........] The king's $k 3$ is the living Horus [......].

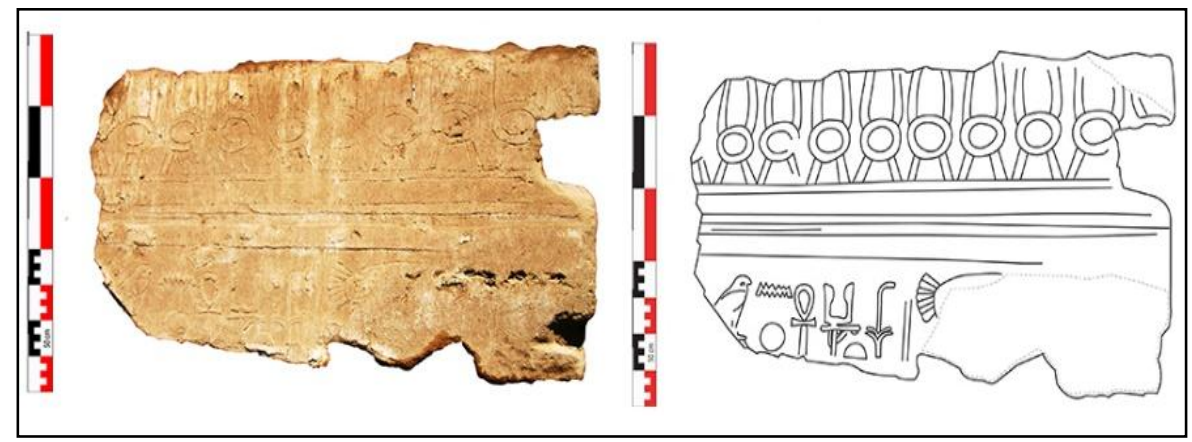

Figure (2-c) shows a block decorated with a part of $h k r$ frieze. 
2.1.4. The southern wall of the hall contains the entrance to the annex $\mathrm{C}$. On the wall is a reused inscribed block and a lintel over the entrance to annex $C$, fig. (3-a).

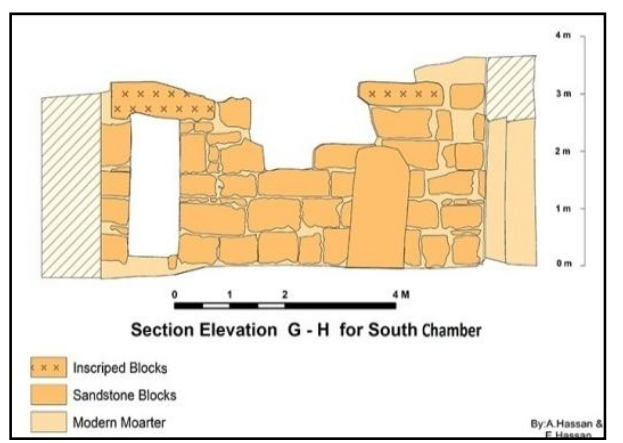

Figure (3-a) shows the reused inscribed blocks in the southern wall of the hall.

In the southern wall of this hall, one can shows two identical columns of text, fig. see that the block at the top of the wall (3-b).

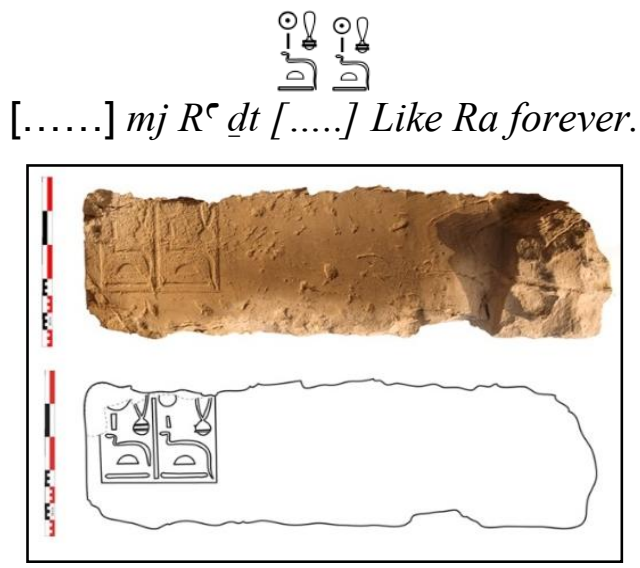

Figure (3-b) shows the block inscribed with two identical columns.

The lintel at the entrance to annex $\mathrm{C}$ displays three horizontal lines of text, fig. (3-c).

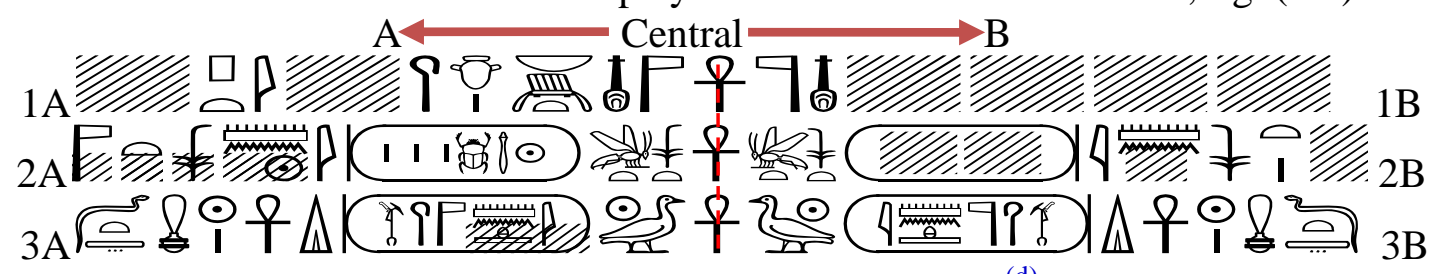

$1 \mathrm{~A}$ `nh ntr nfr nb $3 w t$ ib hkj ... ipt $[s w t]^{(\mathrm{d})}$

1B 'nh ntr nfr [nb 3wt ib hkj ... ipt swt]

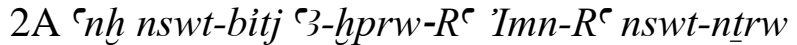
2B 'nh nswt-bitj [`3-hprw-R`] Imn-[R` ] nswt-[ntrw]

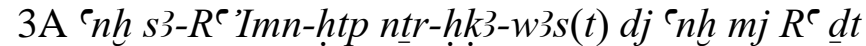

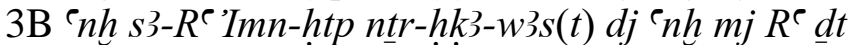

1A May the good god, lord of happiness, the rule of [Karnak], live!

1B May the good god, [lord of happiness, the ruler of Karnak], live!

2A He may live, the king of upper and lower Egypt Aa-kheperu-Ra (beloved of) AmunRa king of the gods.

2B He may live, the king of upper and lower Egypt [Aa-kheperu-Ra] (beloved of) Amun- [Ra] king of [the gods].

3A He may live, the son of Ra Amenhotep the god, the ruler of Thebes, who is given life like Rae forever.

3B He may live, the son of Ra Amenhotep the god, the ruler of Thebes, who is given life like Rae forever. 


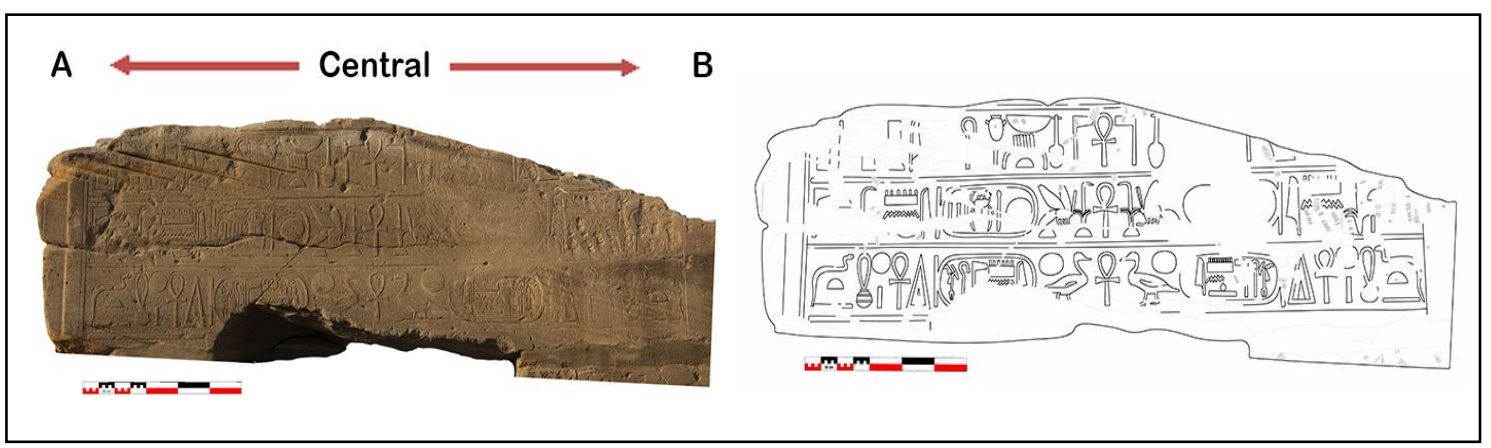

Figure (3-c) shows lintel at the entrance to annex C.

\subsection{The reused blocks in the southern annex $A$}

Annex A is located on the western side of the southern chamber. It is not decorated

with scenes but displays some reused inscribed blocks.

2.2.1. The eastern wall with the entrance doorway contains no reused block.

2.2.2. The northern wall contains a single inscribed block that is reused, fig. (4-a). The block is placed upside down, fig. (4-b). It has remains of a vulture's wing and is inscribed with two columns of text.

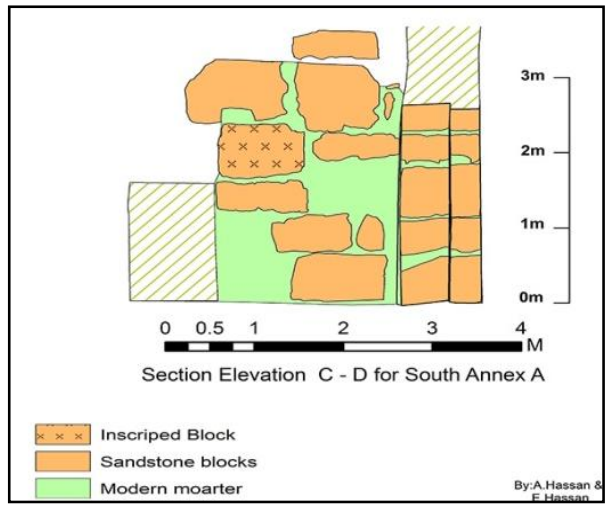

Figure (4-a) illustrates the reused inscribed block in the northern wall of the south annex A.

$$
\underbrace{1-8}_{\text {is }}
$$

$1[\ldots . .]^{`} n h$ w3s 'Imn $R^{\complement} n b$ nswt [t3wj] [.......] life and domination, Amun-Ra Lord [of the two lands] thrones

2 nswt-bitj $n b[t 3 w j]$ the king of upper and lower Egypt, Lord of [the two lands]

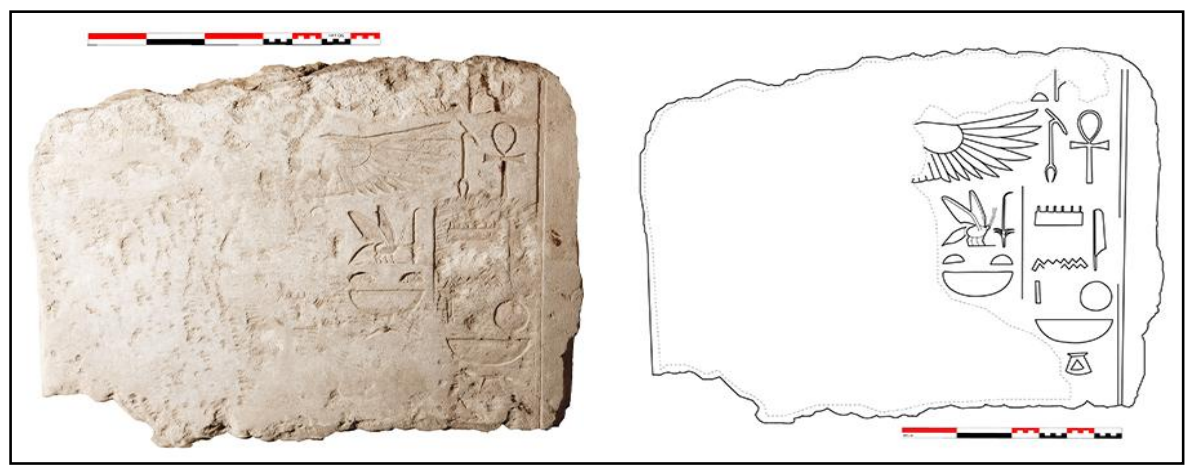

Figure (4-b) illustrates that the block has remains of a vulture's wing. 
2.2.3. The western wall of annex $A$ has one inscribed block in the first register, fig. (5-a).

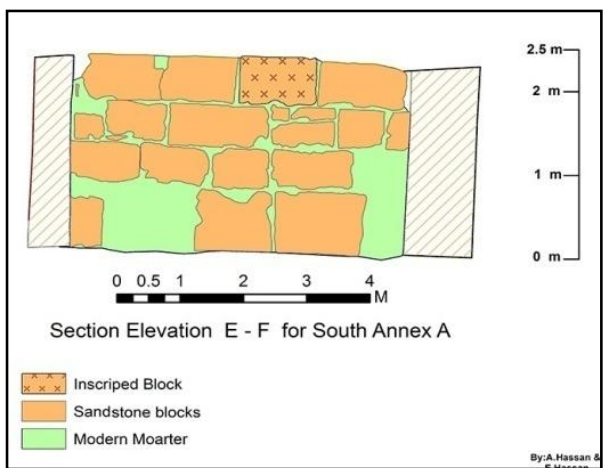

Figure (5-a) shows the reused inscribed block in the western wall of the south annex A.

The block is decorated with the upper part of two crowns: One is the two feathers (Amun's crown), and the other is an 3tf crown. The wing of the vulture holding the $\check{s} n \operatorname{sign}^{(\mathrm{e})}$ in its claw crowns a vertical inscription in three columns fig. (5-b). The author argues that this block is the upper part of one of the chamber's pillars, which represents King Amenhotep II embraced by the $\operatorname{god} \operatorname{Amun}^{(\mathrm{f})}$.

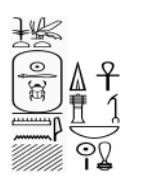

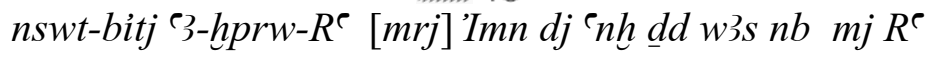

The king of upper and lower Egypt Aa-kheperu-Ra, [beloved of] Amun, who given all life, stability, and authority like Ra.

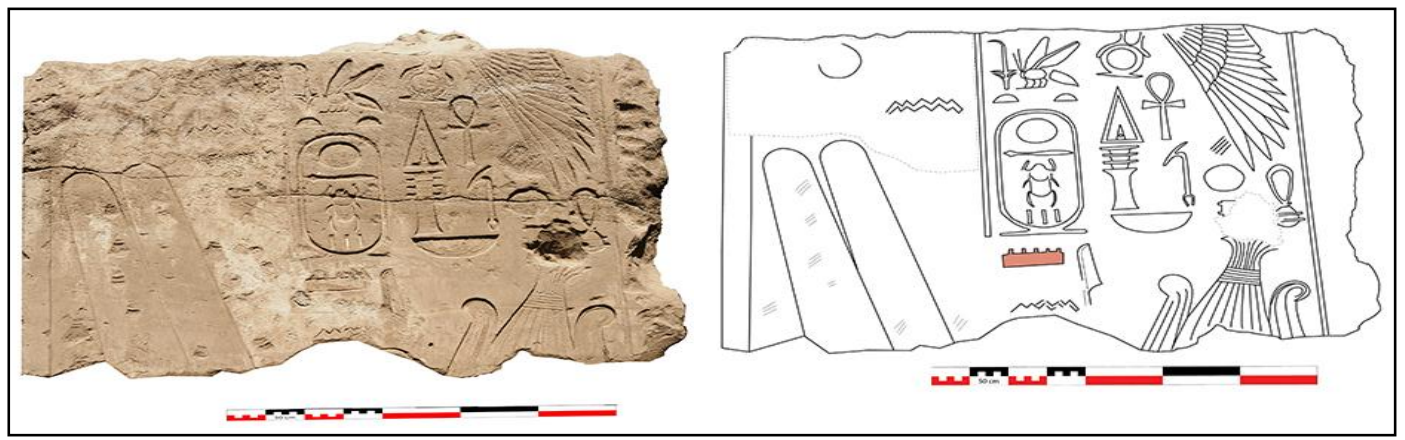

Figure (5-b) shows that the block has an upper part of two crowns.

2.2.4. The southern wall of annex $A$ has a decorated block upside down at the top of the wall, fig. (6-a). It was inscribed with two horizontal lines of text, but they are currently damaged. It displays the remains of a vulture's wing, fig. (6-b).

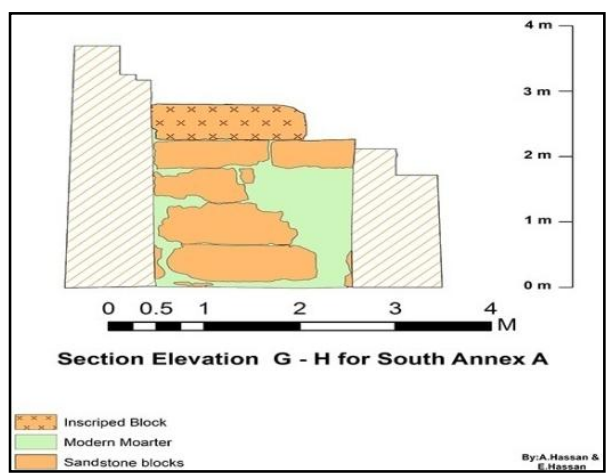

Figure (6-a) shows the reused inscribed block in the southern wall of the south annex A. 


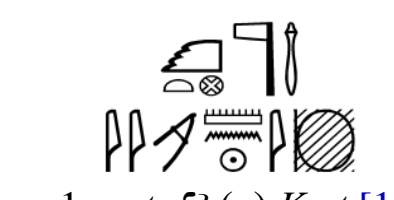

1- ntr $\bigodot_{3}(n) \mathrm{Kmt}[1]$

2- [3-hprw-R] mrj'Imn-R

1- The great god of the black land.

2- [Aa-kheperu-Ra ], beloved of Amun-Ra

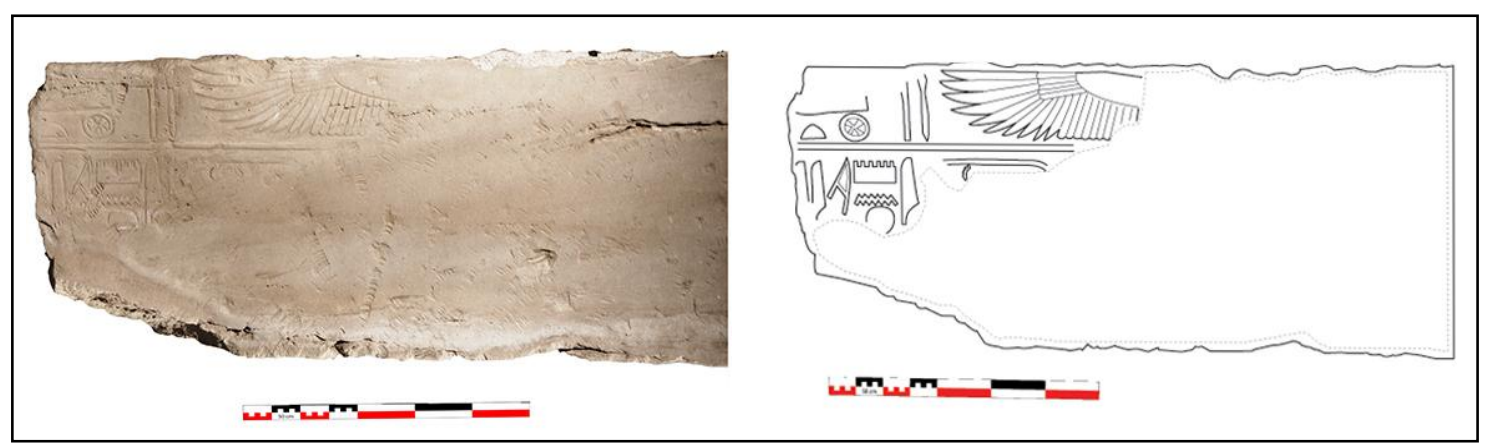

Figure (6-b) shows the block inscribed with two horizontal lines.

\subsection{The reused blocks in the southern annex $B$}

Annex B is located to the south of Annex A, it contains eastern wall of the room with to reused decorated block in the top of the entrance, northern wall, in addition the western wall.

2.3.1. The eastern wall of the room with the entrance has a reused inscribed block, fig. (7-a).

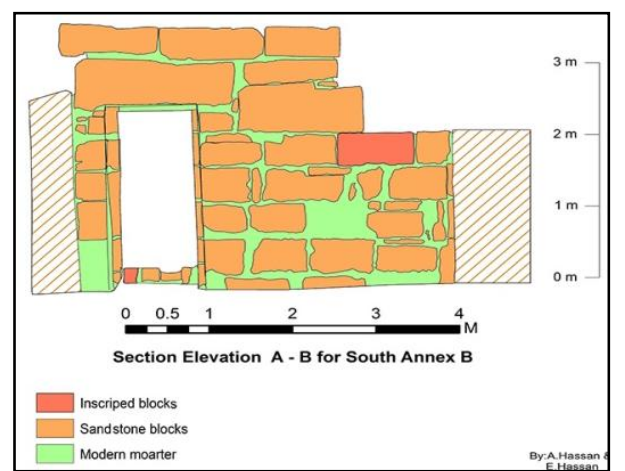

Figure (7-a) shows the reused inscribed block in the eastern wall of the south annex B.

The block is inscribed with two horizontal lines of text. It is clear from the layout of the text that the block was originally a

part of a pillar. The inscriptions name the chapel's function, fig. (7-b).

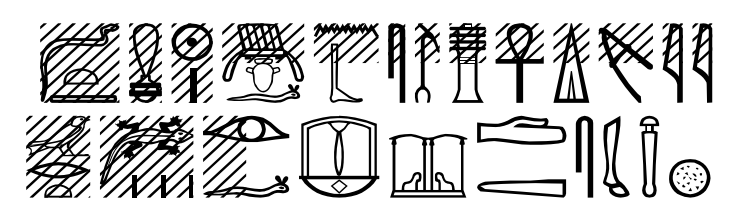

1- dj `nh $\underline{d} d$ w3s snb 3wib.f [mj R` $\left.R^{\ulcorner} t\right]$ mrj [Imn?]

2- sp tpj whm [1,9] hb-sd ir.f [־ॅ了3 wrt]

1-(Amenhotep II) given life, stability, strength, and health, his heart is joyful [like Ra forever], beloved of $[\ldots . . . .]^{(\mathrm{g})}$

2-Repeating the first occasion of the jubilee, may he make [many times]. 


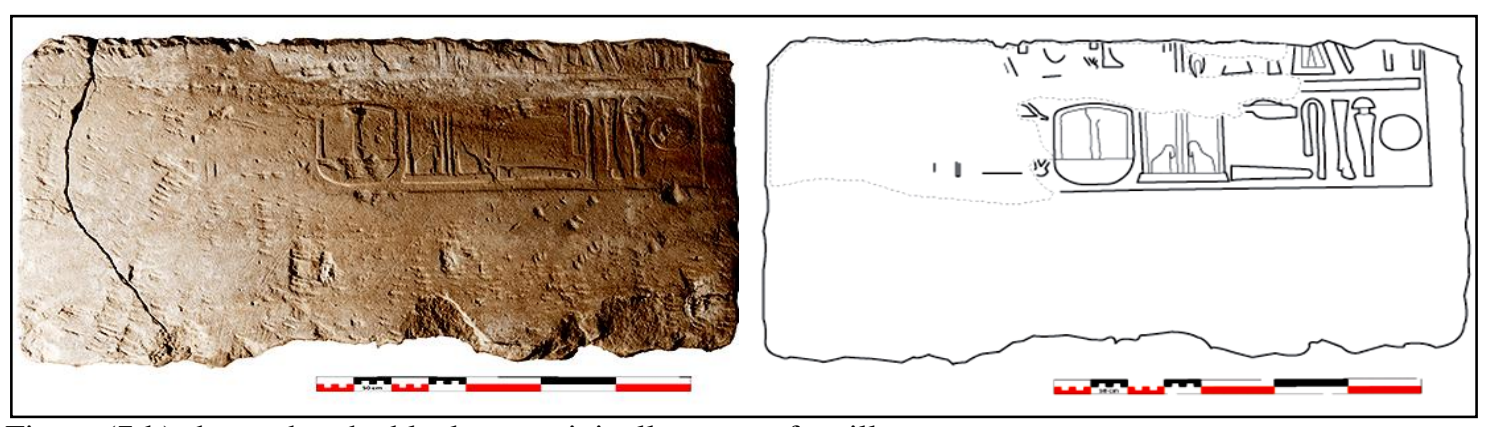

Figure (7-b) shows that the block was originally a part of a pillar.

There is also a sandstone block on the of the king. It is probably from the $X^{\text {th }}$ entrance step. It comes from a very early monument of Amenhotep IV (not yet Akhenaten) with raised relief cartouche pylon. The ankh sign written in sunken relief is probably a later re-carving of the inscription, fig. (7-c).
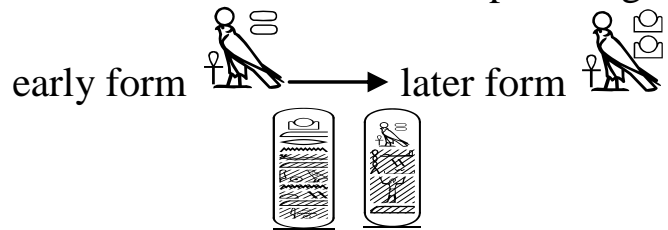

'nh Re-Hr-3hty [h`j m] 3ht $m$ rn[.fm šw m ntj m'Itn]

The living Ra-Horakhty, [rising in] the horizon in his name [as Shu which is in Aten].

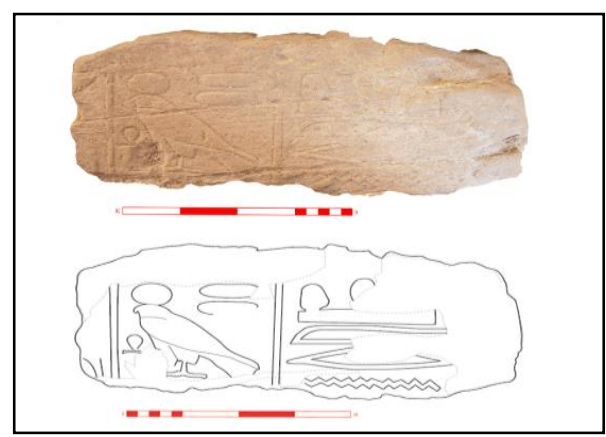

Figure (7-c) shows a block on the entrance step.

2.3.2. The northern wall of annex $B$ has no inscribed blocks.

2.3.3. At the top of the western wall is a reused decorated block, fig. (8-a). It shows the king wearing the royal tunic. A column of text runs behind him, fig. (8-b).

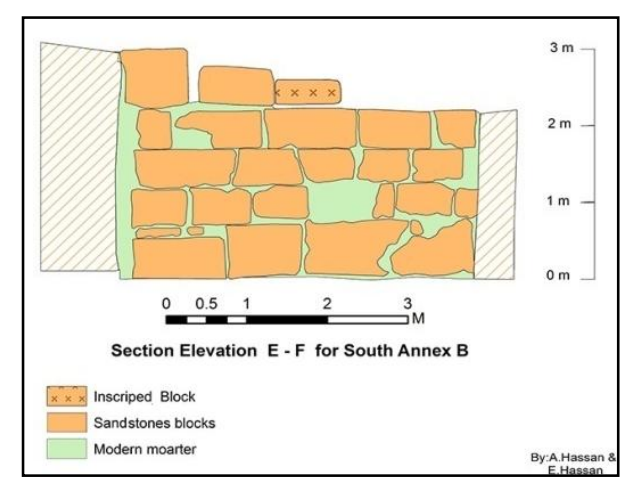

Figure (8-a) shows the reused inscribed blocks in the western wall of the south annex B.

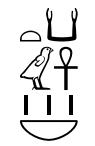

[ir.n.f hntj] $k 3 w{ }^{\complement} n h w n b^{(\mathrm{h})}[\ldots . .$.$] [He was foremost of] the kas of all livings [.....]$ 


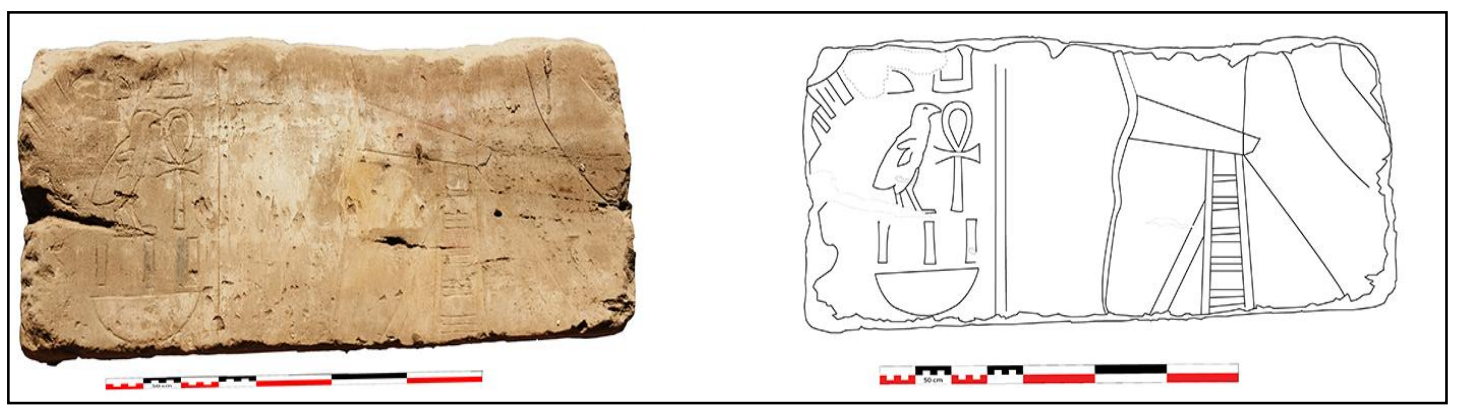

Figure (8-b) shows a block of the king wearing the royal tunic.

2.3.4. The southern wall of Annex B fig. (9-a) depicts the god Amun wearing the two feathers. In front of him, the king pours water from a Hs pot on an offering table containing lettuce, fig. (9-b).

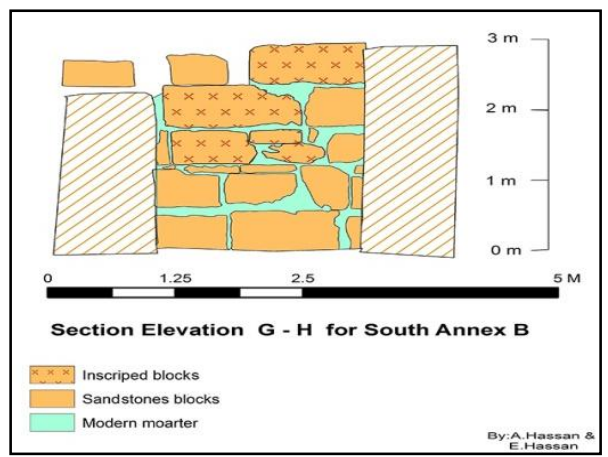

Figure (9-a) shows the reused inscribed blocks in the southern wall of the south annex B.

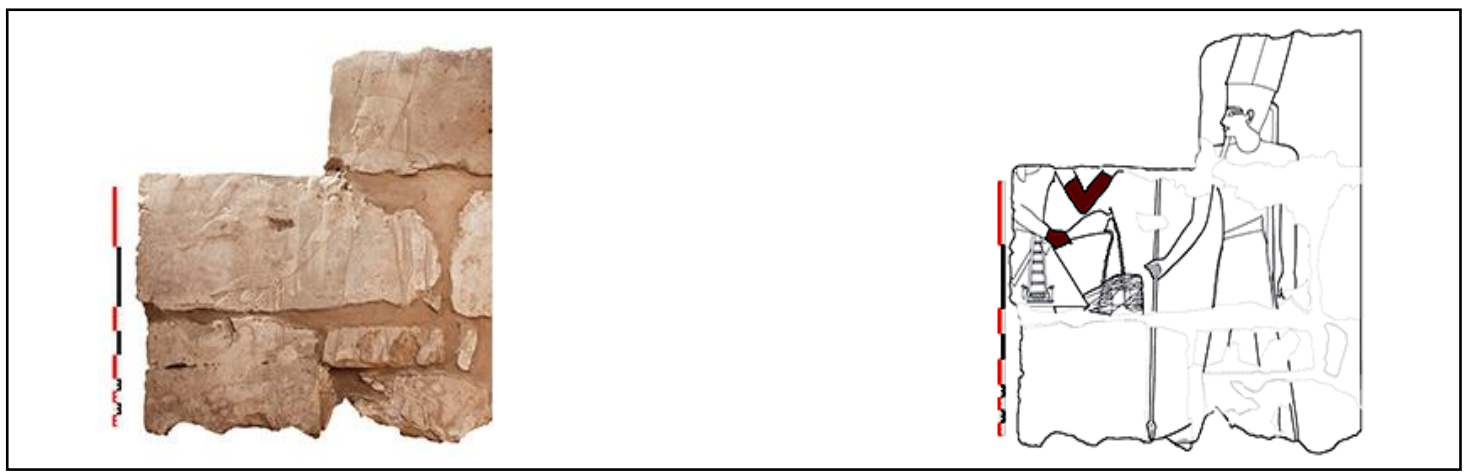

Figure (9-b) shows a scene depicting the god Amun with the king.

\subsection{The reused blocks in the south Annex $C$}

2.4.1. The northern wall of the chamber with the entrance doorway has a number of reused blocks, fig. (10-a).

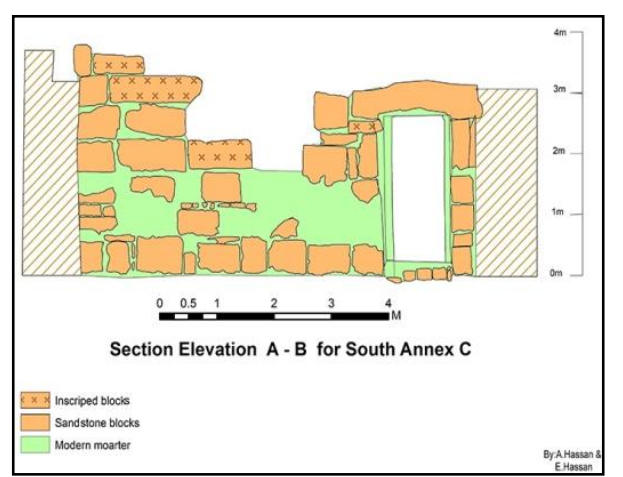

Figure (10-a) shows the reused inscribed blocks in the northern wall of the south annex B. 
The first block next to the doorway shows a series of vertical and horizontal lines reminiscence of a false-door or other types of architectural outlines, fig. (10-b). The second block is a scene representing offerings of three vessels, bread, goose, flowers, plants, and fruits, fig. (10-c). The third block is inscribed with two partial columns of text, fig. (10-d). Moreover, the last block is decorated with a partial figure of the vulture holding the $\check{s} n$ sign in his claw, protecting the cartouche of Amenhotep II 3-hprw-R ${ }^{\ulcorner}$, fig. (10-e).

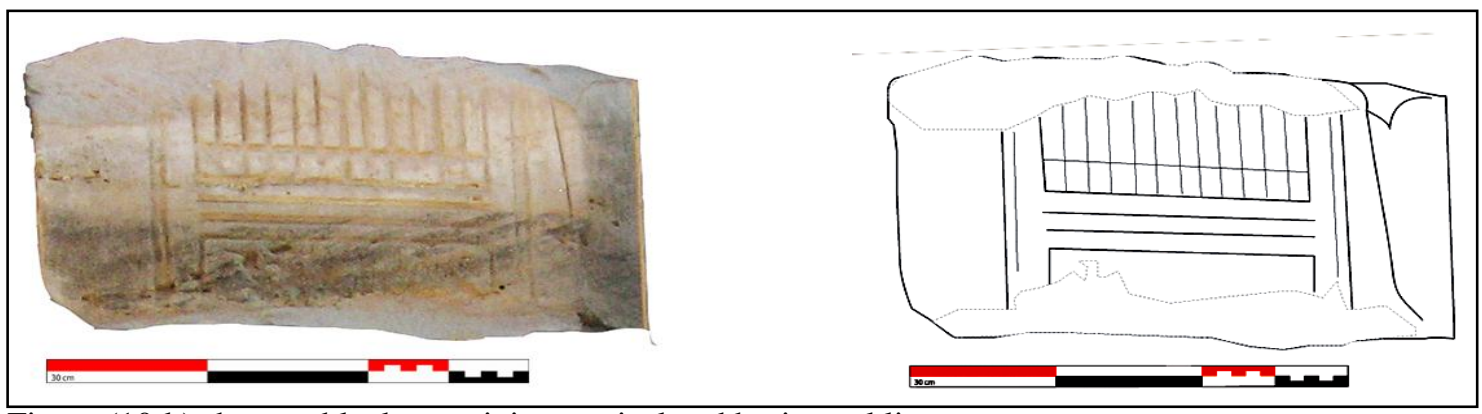

Figure (10-b) shows a block containing vertical and horizontal lines.

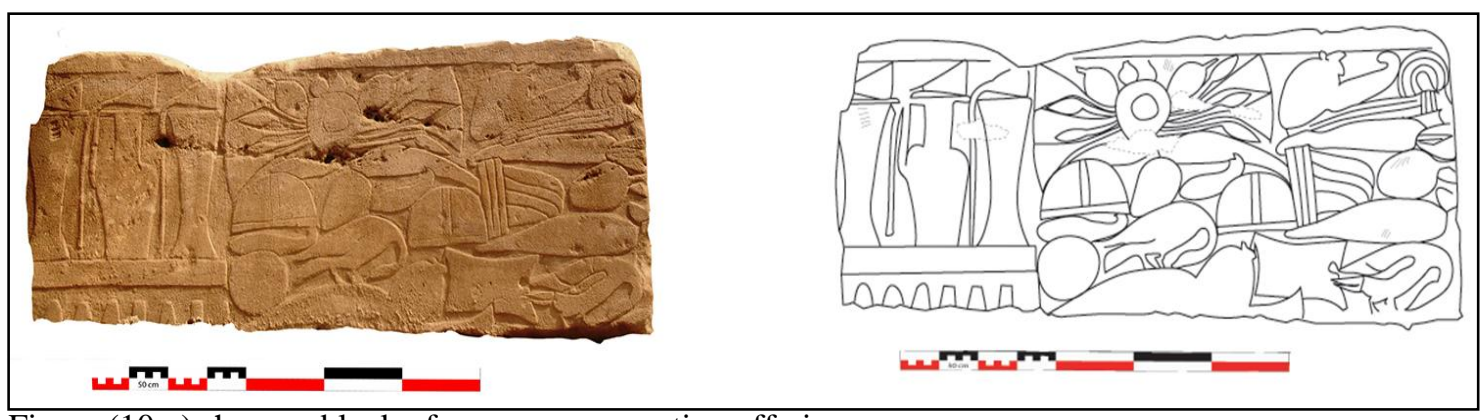

Figure (10-c) shows a block of a scene representing offerings.

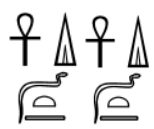

1- [mrj...] dj ${ }^{\mathrm{C}} \mathrm{nh} \underline{\mathrm{d}} \mathrm{t}$ [beloved of....] given life forever

2- [mrj...] dj ' $n h \underline{d} d t$ [beloved of....] given life forever.

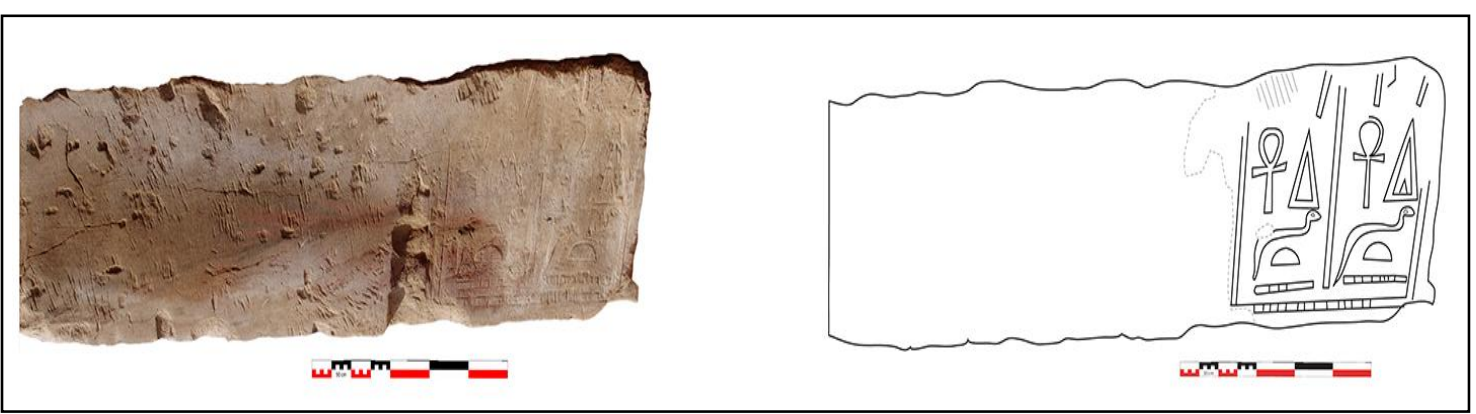

Figure (10-d) shows that the block is inscribed with two partial columns.
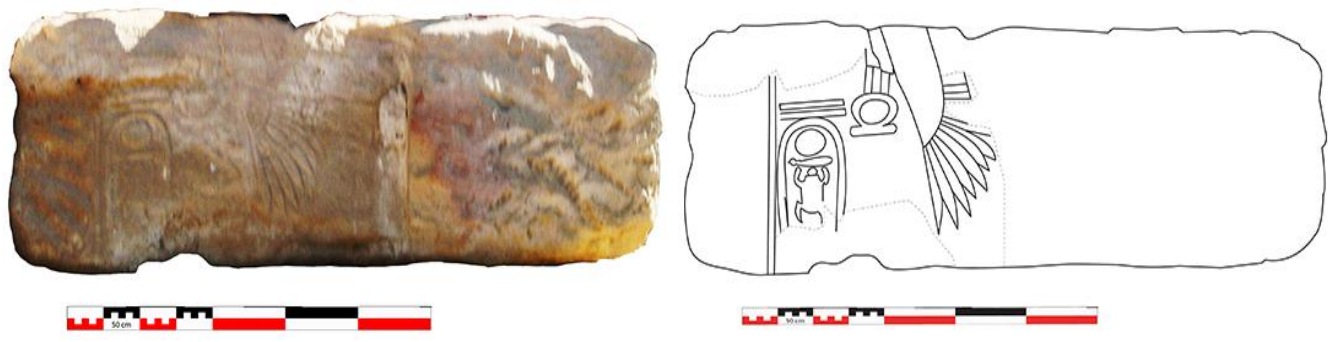

Figure (10-e) shows a block with a partial figure of the vulture. 
2.4.2. The western wall of Annex $C$ displays a block. At the top, fig. (11-a), it has one inscribed column of text, fig. (11-b).

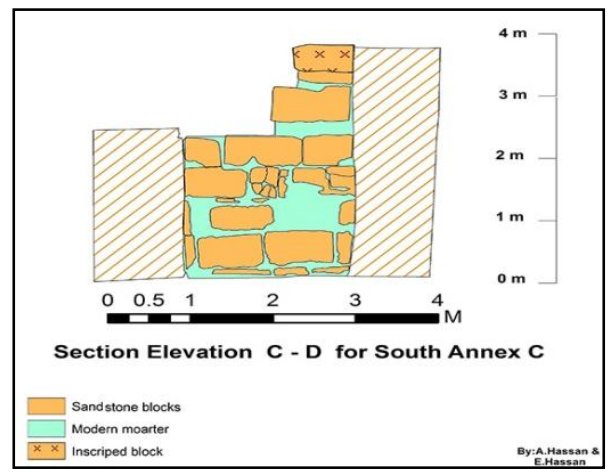

Figure (11-a) shows the reused inscribed blocks in the western wall of the south annex $\mathrm{C}$.

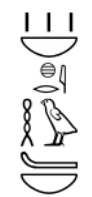

[.....] $n b$ hr.i hw [1,10-12] $n b[h r . i]$ Every [.....] from me, every food [from me].

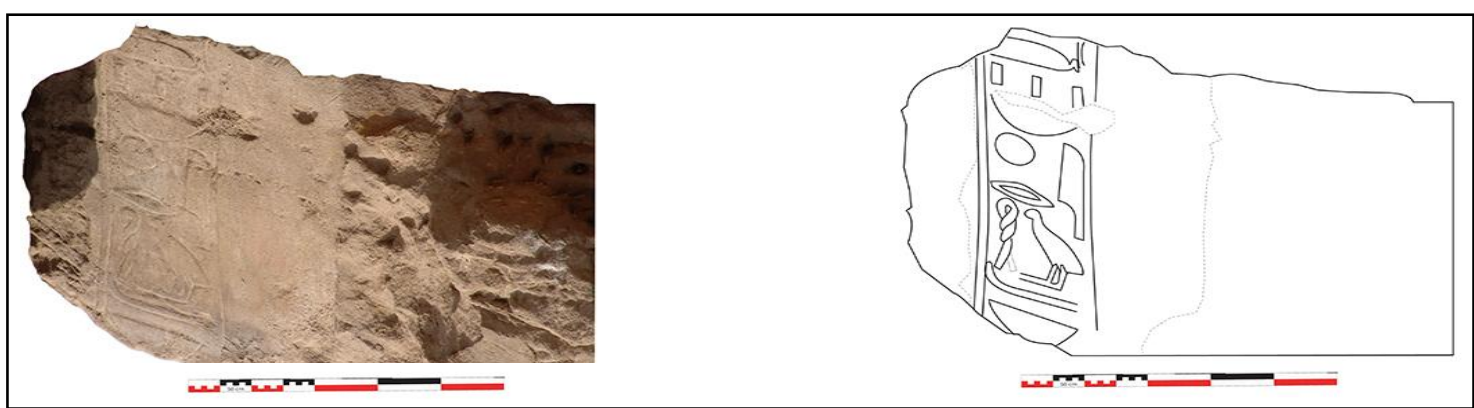

Figure (11-b) shows a block at the western wall of Annex C.

2.4.3.The southern wall of Annex $C$ contains three reused inscribed blocks, fig. (12-a).

The first block depicts two figures separated by a column of text; on the left the god Amun, on the right the king, fig. (12-b). The second block shows Amenhotep II wearing the $n m s$ with uraeus and holding two $n w$ vase. In front of him, there is an offering table. The inscription above the king's head displays his name in two cartouches, one

of which is erased, fig. (12-c). A third block represents Amenhotep II wearing the white crown with the uraeus and holding two $n w$ vases. In front of him, there are two cartouches: The first reads '3-hprw-R`, while the second cartouche is damaged and reads: $[\ldots .] m j.\left[R^{\Upsilon}\right]$ "[....] like Ra", fig. (12-d).

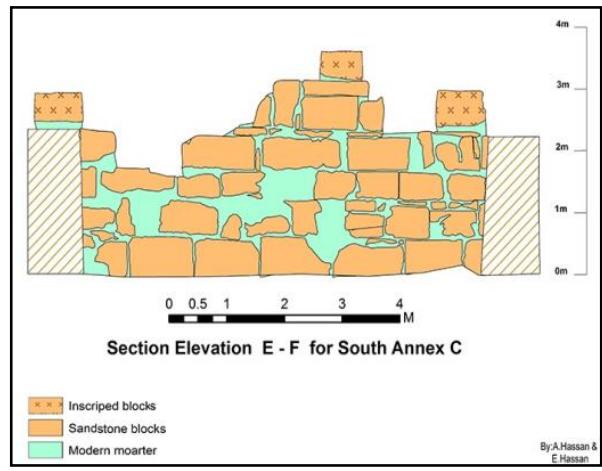

Figure (12-a) shows the reused inscribed blocks in the southern wall of the south annex C. 


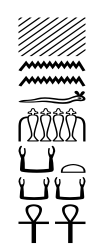

$[\ldots . . . n] n . f$ hntj $k 3 w[13]{ }^{`} n h w[\ldots . .$.

[......] to him the foremost of the souls of the living [......]

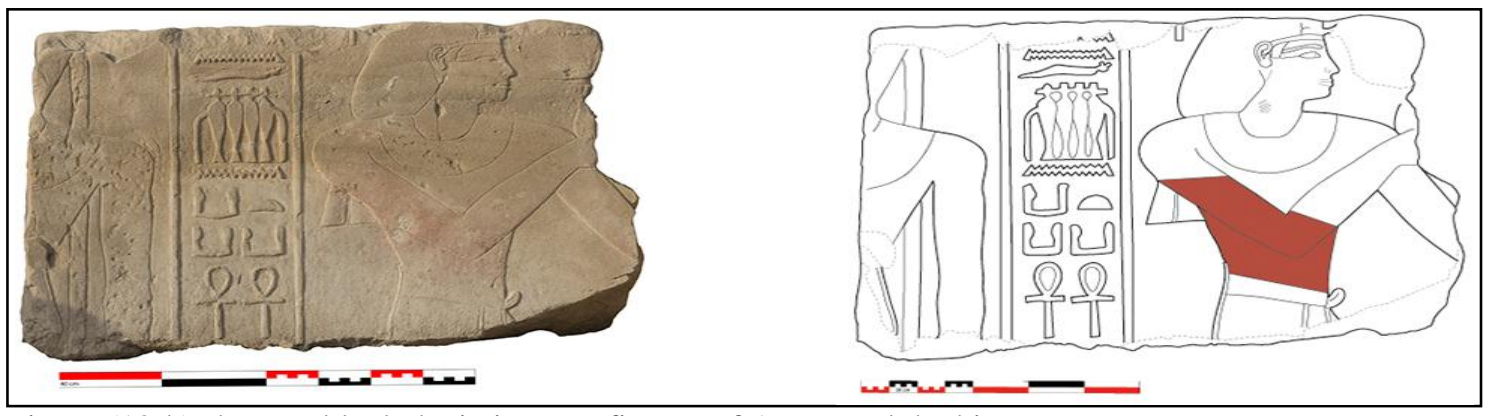

Figure (12-b) shows a block depicting two figures of Amun and the king.

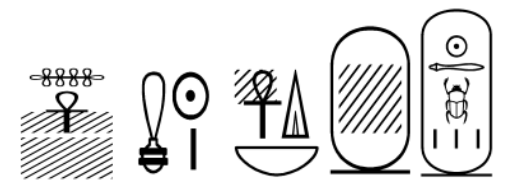

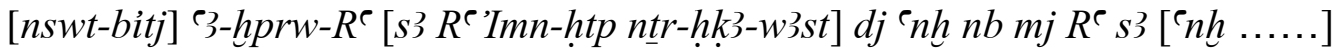

[The king of upper and lower Egypt] Aa-kheperu-Ra, [the son of Rae Amenhotep the god, the ruler of Thebes], given all life like Ra, protection [....]

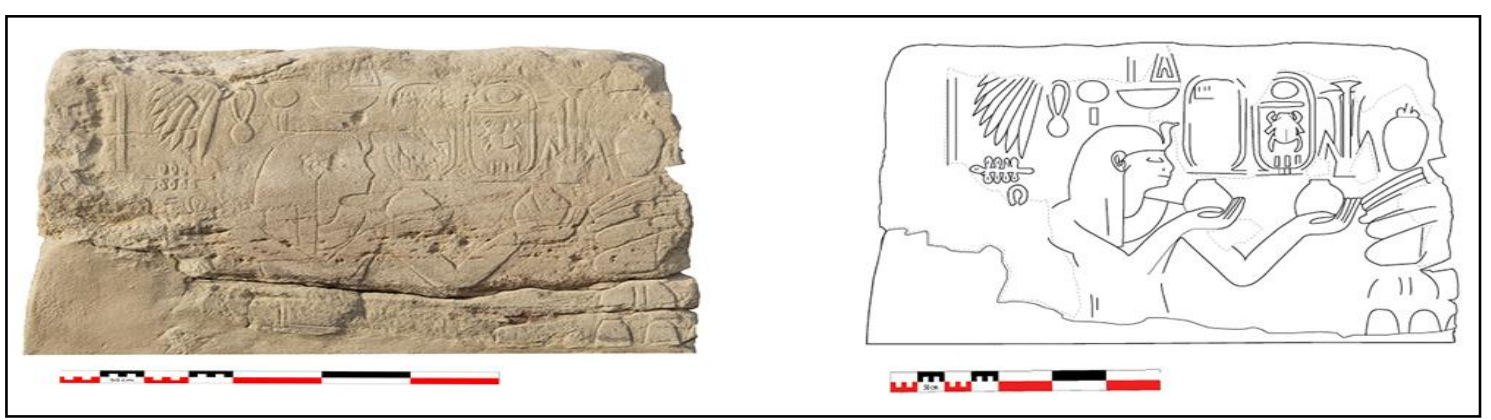

Figure (12-c) shows a block that depicts Amenhotep II holding $n w$ vase.

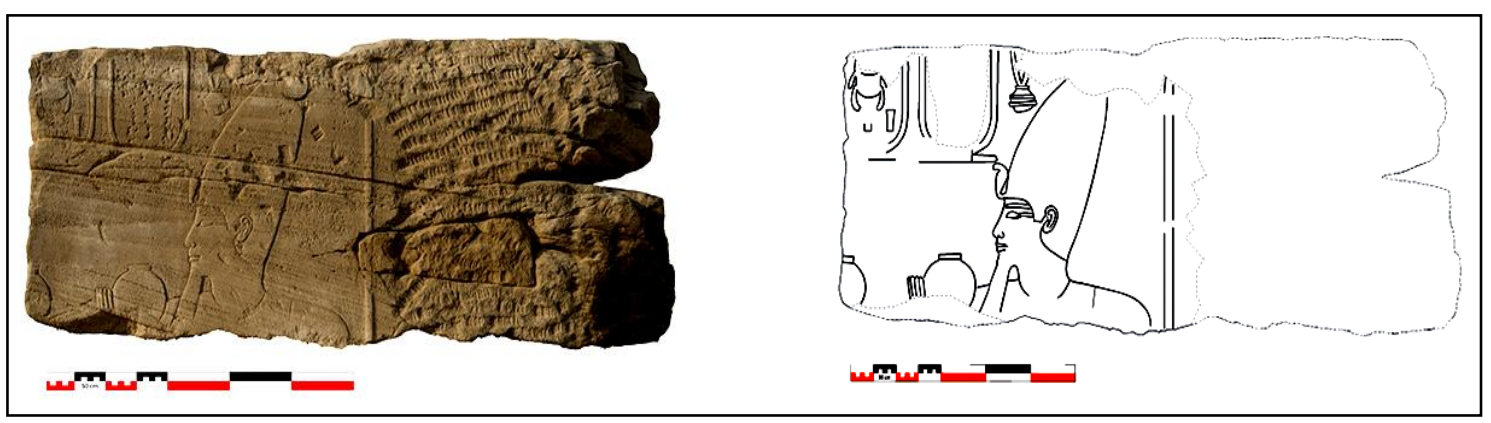

Figure (12-d) shows a block that represents Amenhotep II wearing the white crown.

2.4.4. The eastern wall of Annex $C$ does not include reused inscribed blocks.

\section{Results}

Analyzing the previous data reveals that the scenes of the reused blocks are for Amenhotep II's second jubilee, but they are used in other places. A purification scene and an offering scene that represents the offerings of three vessels, bread, goose, 
flowers, plants and fruits, and title of Amenhotep II. Some blocks were originally part of a pillar. The inscriptions' name the edifice's function and represent king Amenhotep II embraced by the god Amun. Although one comes from a very early monument of Amenhotep IV (not yet Akhenaten) with raised relief cartouche of the king, it is probably from the $\mathrm{X}^{\text {th }}$ pylon.

\section{Discussion}

The edifice of Amenhotep II was dedicated to the $h b-s d$ festival. Most of the reused blocks of the study date back to the era of Amenhotep II [14]. The inscriptions name the edifice's function, but some of these blocks come from the $\mathrm{X}^{\text {th }}$ pylon $[3,4]$.

\section{Conclusion}

Most of the blocks of the study date back to the era of Amenhotep II. They mostly represent the $h b$-sd festival and Amenhotep II titles, but others are due to different later eras like Akhenaton. The reused blocks will be identified after the entire chapel is studied. The author will try later virtual reconstruction when completing the study of the edifice of Amenhotep II.

\section{Endnotes}

(a) I thank the permanent committee of the Egyptian ministry of antiquities, the managers of Karnak temple, and the Egyptian-French center for the study of Karnak temples for allowing me to study and publish this monument. My thanks go to Mr. Ahmed Hassan and ElAzab Hassan.

(b) Stele des Antef (Louvre C 167= E 3111): "nsw-bjtj hpr-k3-re ntr-nfr nb-t3wj nbjrit-ht the king of upper and lower Egypt Kheperkare, the good god, lord of the two tands, tord of ritual practices". The stela is currently heavily damaged. Only one-third of the text is preserved. However, an early copy of the entire text by James Burton was published by R. Moss (1932, 310-311).

(c) $h k r$ frieze was formed by certain floral or geometric images, repeated along with the parts of the building. It was used in architectural decoration, furniture, and decoration. The friezes are common decorative designs, simply depicting stylized bundles of reeds or plant stem in Ancient Egypt [15,16].

(d) $\otimes_{0 \text { o }}^{\circ} \circ \circ$ ipt swt $[1,10,17]$.

(e) The vulture or the falcon Horus above the king holds the $\check{n} n$ sign, which hangs the signs of $[n h, w 3 s$ - symbols of protection, life, and eternity. The $\check{s} n$ gives the concept of immortality or eternity through its shape and solar.

(f) In other studies, the block shall reconstruction in its original position.

(g) $m r j$ (Imn) beloved of (Amun) is figured on the chamber's pillars with Amenhotep II.

(h) The titulary attested on the red chapel of Hatshepsut is $\underline{h} n t j k 3 w^{`} n h w$ ' foremost of the kas of all livings'[18].

\section{Reference}

[1] Erman, A. \& Grapow, H., (1982). Wörterbuch der Ägyptischen sprache, $6 \mathrm{Vol}_{s}$., Akademia-Verlag, Berlin.

[2] Schwaller de Lubiez, R.., (1999). The temples of Karnak, Thames \& Hudson, London.

[3] Aldred, C., (1967). The second jubilee of Amenhotep II, ZÄS, Vol. 97 (2), pp. $1-6$

[4] Van Siclen, C., (1990). Preliminary report on epigraphic work done in the edifice of Amenhotep II, seasons of 1988-89 and 1989-90, VA, Vol. 6, pp. 75-90.

[5] Barguet, P., (1962). Le temple d'AmonRe à Karnak, Imprimerie De L'Institut Français D'Archéologie Orientale, Caire.

[6] Porter, B. \& Moss, R., (1972). Topographical bibliography of ancient Egyptian hieroglyphic texts, reliefs, and paintings, II. Theban temples, Griffith Institute, Oxford.

[7] Nelson, H., (1941). Key plans showing locations of Theban temple decorations, OIP, Vol. 56, University of Chicago, USA.

[8] Leitz, C., (2002). Lexikon der ägyptischen götter und götterbezeichnungen, 7 Vol $_{\text {s., }}$ Peeters Pub \& Department of Oriental Studies, Leuven.

[9] Gardiner, A., (1927). Egyptian, grammar, being an introduction to the study of 
hieroglyphs, Griffith Institute Ashmolean Museum, Oxford.

[10] Faulkner, R., (1976). A concise dictionary of middle Egyptian, Griffith Institute, Oxford.

[11] Lesko, L., (1982-1990). A dictionary of late Egyptian, $5 \mathrm{Vol}_{\mathrm{s}}$., $2^{\text {nd }}$ ed., B.C. Scribe Pub., Berkeley.

[12] Wilson, P., (1997). A Ptolemaic lexikon: A lexicographical study of the texts in the temple of Edfu, OLA 78, Peeters Publishers, Sweden

[13] Hannig, R., (1995). Großes handworterbuch, Ägyptisch-Deutsch, Verlag Philipp von Zabern, Mainz.
[14] Van Siclen, C., (2005). La cour du IXe pylône à Karnak, Bulletin de la société d'égyptologie, Vol. 163, pp. 27-46.

[15] Mackay, E., (1920). Kheker friezes, Ancient Egypt, Vol. I, pp.111-122.

[16] Shehab, N., \& Xkr (Kheker) frieze in ancient Egypt", J. of the General Union of Arab Archaeologists, Vol. 2, pp. 132-158.

[17] Barguet, P., (1980). Kanak, in: $L \ddot{A}$, Vol. III, pp. 341- 352.

[18] Kitchen, K., (1983). Ramesside inscriptions, historical and biographical, Vol. VI, B.H. Blackwell, Oxford. 